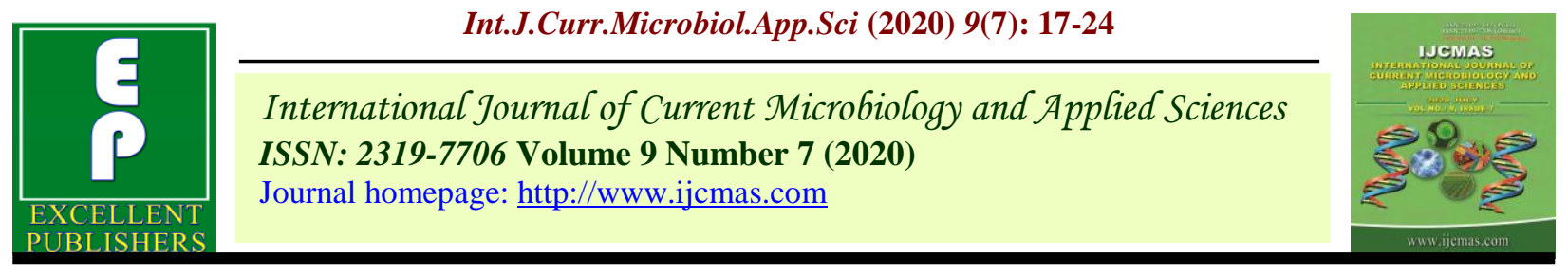

Original Research Article

https://doi.org/10.20546/ijcmas.2020.907.003

\title{
Evaluation of Antibacterial Activity of some Indian Herbal Extracts
}

\author{
R. Kavitha*, C. Valli, R. Karunakaran, K. Vijayarani and R. Amutha \\ Department of Animal Nutrition, Madras Veterinary College, Vepery, Chennai - 600007 , \\ Tamil Nadu Veterinary and Animal Sciences University, India \\ *Corresponding author
}

Ke y w o r d s
Antibacterial
activity, Indian
herbs, Herbal
extracts

\section{A B S T R A C T}

Sixteen traditional medicinal herbs that are used in Indian traditional medicine and which are commonly available in Tamil Nadu were collected for the study. Different medicinal parts of the herbs were selected and dried and grounded under aseptic condition. To determine the in vitro antimicrobial effect, aqueous and ethanol extracts were prepared and tested against Staphylococcus aureus, Escherichia coli, Salmonella entitidis and Clostridium perfringens. Allium sativum bulbs (Garlic) showed significantly higher zone of inhibition against Staphylococcus aureus, Escherichia coli and Salmonella entitidis when compared with Syzygium aromaticum bud (Clove). Other extracts evinced no zone of inhibition. In the case of Clostridium perfringens, Syzygium aromaticum bud (clove) was the only herb showed zone of inhibition. Among the ethanol extracts tested Syzygium aromaticum bud (Clove) showed significantly $(\mathrm{p}<0.05)$ higher zone of inhibition against Staphylococcus aureus, Escherichia coli and Salmonella entitidis. Murraya koenigii leaves (Curry leaves) was found to have highest zone of inhibition against Clostridium Perfringens.

\section{Introduction}

The past three decades has witnessed the production of various new antibiotics by pharmacological industries for treatment of bacterial diseases. The use of antibiotics at sub therapeutic dose as growth promoters, also was on the increase. The overuse and misuse of antibiotics has led to genetic mutation in bacteria leading to the development of bacterial resistance to antibiotics. A surge in the development and spread of antibiotic resistance has become a major cause for concern (Aarestrup et al., 2008). The quest for alternative products has clearly intensified in the recent years with the increase in regulations regarding the use of antibiotic growth promoters and the rise in consumer demand for poultry products from "Raised Without Antibiotics" or "No 
Antibiotics Ever" flocks (Gadde et al., 2017). Currently there has been an increased awareness on usage of traditional herbal medicine as alternative to antibiotics. These herbal preparations of plant origin are easily available, inexpensive, safe, efficient, and rarely cause any side effects. Plants have an amazing ability to produce a wide variety of secondary metabolites, like alkaloids, glycosides, terpenoids, saponins, steroids, flavonoids, tannins, quinones and coumarins (Tiwari et al., 2010). These secondary plant metabolites are a source of plant derived antimicrobial substances (Srivastava et al., 2013). Some of these natural plant products are highly efficient in the treatment of bacterial infections (Fernebro et al., 2011). It is with this background the evaluation of antibacterial activity of extracts of some traditional herbs commonly available in Tamil Nadu was undertaken.

\section{Materials and Methods}

\section{Collection of herbal samples}

Sixteen traditional medicinal herbs Allium sativum, Andrographis paniculata, Azadirachta indica, Cinnamomum verum, Coriandrum sativum, Curcuma longa, Emblica officinalis, Mentha spicata, Moringa oleifera, Murraya koenigii, Ocimum sanctum, Phyllanthus niruri, Piper nigrum, Syzygium aromaticum, Trigonella foenum and Zingiber officinale that are used in Indian traditional medicine and which are commonly available in Tamil Nadu were collected for the study.

Different parts of the herbs have different active principles, and hence the part that is traditionally used for medicinal purpose was selected for each particular herb. The herbs and their parts selected for the study are listed in table 1 .

\section{Preparation of the herbal extracts}

The plant samples (250 gms) were suitably cleaned from extraneous matter, shade dried for 72 hours and ground to pass through $1 \mathrm{~mm}$ sieve using a Willey mill under aseptic conditions (Haniyeh et al., 2010). The ground samples were then stored in air tight containers. To determine the in vitro antimicrobial effect of the samples, aqueous and ethanol extracts of the herbal samples were first prepared. To prepare aqueous extract, the ground samples, $100 \mathrm{mg}$ each were taken in a sterile eppendorf tubes to which was added $1 \mathrm{ml}$ of sterile water, vortexed and kept in refrigerator overnight. To prepare ethanol extract, the ground samples, $100 \mathrm{mg}$ each were taken in a sterile eppendorf tubes to which was added $1 \mathrm{ml}$ of 95\% ethanol, vortexed and kept in refrigerator overnight. Hence, for each of the herbal sample, aqueous and ethanol extracts were prepared. Each of these extracts (aqueous and ethanol) were tested for their in vitro antibacterial activity.

\section{Preparation of microorganisms}

The microorganisms under study were Staphylococcus aureus, Escherichia coli, Salmonella entitidis and Clostridium perfringens. They were isolated from the clinical samples obtained from Poultry Disease Diagnosis and Surveillance Laboratory, Veterinary College and Research Institute, Namakkal. The organisms were isolated in nutrient agar medium and selectively cultured at $37{ }^{0} \mathrm{C}$ for $24 \mathrm{hrs}$. The bacterial strains were identified by gram staining and confirmed by biochemical tests as per the directions from Bergy's manual for determinative bacteriology.

\section{In vitro antimicrobial assay}

To determine the in vitro antimicrobial effect of the herbal samples, sterilized circular disc, microbial cultures (Staphylococcus aureus, Escherichia coli, Salmonella entitidis and Clostridium perfringens) aqueous and ethanol 
extracts of the herbal samples were first prepared and kept ready.

Circular disc of $6 \mathrm{~mm}$ diameter were made from the Whatman no 1 filter paper. Discs were impregnated with equal volume $(15 \mu \mathrm{l})$ of the respective plant extracts (aqueous / ethanol). The discs were aseptically placed over plates of Mueller Hinton agar for Staphylococcus aureus, Mac Conkey agar for Escherichia coli and Nutrient agar for Salmonella entitidis and Clostridium Perfringens agar for Clostridium perfringens, seeded with the respective test pathogens. After drying in the air, the plates were incubated at $37{ }^{0} \mathrm{C}$ for 24 hours. For the Clostridium perfringens, the plates were kept in an anaerobic jar in an upright position at 37 ${ }^{0} \mathrm{C}$ for 24 hours. Sterile water and $95 \%$ ethanol were used as control respectively for aqueous and ethanol extracts of samples. Further the inoculums were adjusted to 0.5 Mc Fairland turbidometry (Haniyeh et al., 2010).

The sensitivity of the microorganism species to the plant extracts (aqueous / ethanol) were determined by measuring the size of the inhibitory zones (including the diameter of the disc) on the agar surface around the discs using zone of inhibition scale. Inhibition zones with diameter values $8 \mathrm{~mm}$ were considered as not active against microorganisms and zones less than $12 \mathrm{~mm}$ were considered as having low antibacterial activity. Diameters between 12 and $16 \mathrm{~mm}$ were considered moderately active, and these with $>16 \mathrm{~mm}$ were considered highly active (Indu et al., 2006).

\section{Results and Discussion}

The aqueous extracts of sixteen herbs tested for antibacterial activity on four poultry pathogens are presented in Table 2, 3. Aqueous extract of Allium sativum bulbs (Garlic) and Syzygium aromaticum bud
(Clove) were the only candidates that showed zone of inhibition against Staphylococcus aureus. Significantly $(\mathrm{p}<0.05)$ higher zone of inhibition was evinced by Allium sativum bulbs (Garlic) (13.67 \pm 0.21$)$ when compared with Syzygium aromaticum bud (Clove) (10.50 \pm 0.22$)$. In the case of Escherichia coli only Allium sativum bulbs (Garlic) (12.50 \pm 0.22 ) had moderate antibacterial activity. The aqueous extracts of other herbs evinced no zone of inhibition. For Salmonella entitidis, Allium sativum bulbs (Garlic) and Syzygium aromaticum bud (Clove) were the only candidates that showed zone of inhibition. Allium sativum pods (Garlic) $(14.67 \pm 0.21)$ had significantly $(\mathrm{p}<0.05)$ higher zone of inhibition (mm) when compared with Syzygium aromaticum bud (Clove) (12.50 \pm 0.34). The aqueous extracts of other herbs evinced no zone of inhibition. Allicin is the active ingredient of garlic that acts by partially inhibiting DNA and protein synthesis and also totally inhibiting RNA synthesis as a primary target (Eja et al., 2007). Organo sulfur compounds and phenolic compounds have also been reported to be involved in the garlic antimicrobial activity (Griffiths et al., 2002 and Jombo et al., 2011). Among the aqueous extracts tested Syzygium aromaticum (Clove) $(15.00 \pm 0.00)$ was the only herbal extract found to have significant moderate antibacterial activity against Clostridium Perfringens. The other herbal extracts evinced no zone of inhibition.

Among the ethanol extracts tested Coriandrum sativum seeds (Coriander), Curcuma longa dry tuber (Turmeric) Murraya koenigii leaves (Curry leaves) and Syzygium aromaticum bud (Clove) were found to have antibacterial activity against all the four organisms tested. In the case of Staphylococcus aureus significantly $(\mathrm{p}<0.05)$ higher zone of inhibition was noted by Syzygium aromaticum bud (Clove) (21.00 \pm 0.00) when compared with other herbal ethanol extracts. Piper nigrum seeds (Black 
pepper) $(19.67 \pm 0.21)$ had the second place. In the case of Escherichia coli, Syzygium aromaticum bud (Clove) $(20.33 \pm 0.21)$ had the significantly $(\mathrm{P}<0.05)$ highest anti bacterial activity than other ethanol extracts of other herbs. Cinnamomum verum bark (Cinnamon) had significantly $(\mathrm{P}<0.05)$ highest antibacterial activity next to Syzygium aromaticum bud, as compared to ethanol extracts of other herbs. For Salmonella entitidis, Syzygium aromaticum bud (Clove) $(17.50 \pm 0.22)$ was found to have significantly $(\mathrm{p}<0.05)$ higher zone of inhibition when compared ethanol extracts of other herbs. Andrographis paniculata leaf with stem (Nilavembu), Azadirachta indica leaves (Neem), Cinnamomum verum bark (Cinnamon), Ocimum sanctum leaves (Tulsi),
Phyllanthus niruri leaves (Keelanelli), Piper nigrum seeds (Black pepper) and Trigonella foenum seeds (Fenugreek) were found to have no zone of inhibition. Essential oils are potential sources of novel antimicrobial compounds especially against bacterial pathogens (Prabuseenivasan et al., 2006). The high levels of eugenol present in clove essential oil is responsible for its strong antimicrobial activities. It is well known that both eugenol and clove essential oil phenolic compounds can denature proteins and react with cell membrane phospholipids changing their permeability and inhibiting a great number of gram-negative and gram-positive bacteria as well as different types of yeast (Chaieb et al., 2007, Walsh et al., 2003).

Table.1 List of herbs and their part selected for the study

\begin{tabular}{|c|l|l|l|}
\hline $\begin{array}{c}\text { S. } \\
\text { No }\end{array}$ & \multicolumn{1}{|c|}{$\begin{array}{c}\text { Botanical name of the } \\
\text { herb }\end{array}$} & $\begin{array}{c}\text { Common name of the } \\
\text { herb }\end{array}$ & \multicolumn{1}{|c|}{ Plant part used } \\
\hline 1 & Allium sativum & Garlic & Bulb \\
\hline 2 & Andrographis paniculata & Nilavembu & Leaf with stem \\
\hline 3 & Azadirachta indica & Neem & Leaf \\
\hline 4 & Cinnamomum verum & Cinnamon & Bark \\
\hline 5 & Coriandrum sativum & Coriander & Seed \\
\hline 6 & Curcuma longa & Turmeric & Rhizome \\
\hline 7 & Emblica officinalis & Amla & Fruit \\
\hline 8 & Mentha spicata & Mentha & Leaf \\
\hline 9 & Moringa oleifera & Moringa leaves & Leaf \\
\hline 10 & Murraya koenigii & Curry leaves & Leaf \\
\hline 11 & Ocimum sanctum & Tulsi & Leaf \\
\hline 12 & Phyllanthus niruri & Keelanelli & Full plant with root \\
\hline 13 & Piper nigrum & Black pepper & Flower bud \\
\hline 14 & Syzygium aromaticum & Clove & Flower bud \\
\hline 15 & Trigonella foenum & Fenugreek & Seed \\
\hline 16 & Zingiber officinale & Dry ginger & Rhizome \\
\hline
\end{tabular}


Table.2 In vitro antimicrobial activity against Staphylococcus aureus, Escherichia coli, Salmonella entitidis and Clostridium perfringens of aqueous extracts of herbs

\begin{tabular}{|c|c|c|c|c|c|}
\hline \multirow[t]{2}{*}{ S.No } & \multirow[t]{2}{*}{ Name of the herb } & \multicolumn{4}{|c|}{ Antimicrobial activity (Zone of inhibition in $\mathbf{m m}$ ) } \\
\hline & & $\begin{array}{c}\text { Staphylococcus } \\
\text { aureus, }\end{array}$ & $\begin{array}{l}\text { Escherichia } \\
\text { coli }\end{array}$ & $\begin{array}{l}\text { Salmonella } \\
\text { entitidis }\end{array}$ & $\begin{array}{l}\text { Clostridium } \\
\text { perfringens }\end{array}$ \\
\hline 1 & Allium sativum (Garlic) & $13.67^{\mathrm{a}} \pm 0.21$ & $12.50^{\mathrm{a}} \pm 0.22$ & $14.67^{\mathrm{a}} \pm 0.21$ & NZI \\
\hline 2 & Andrographis paniculata (Nilavembu) & NZI & NZI & NZI & NZI \\
\hline 3 & Azadirachta indica (Neem) & NZI & NZI & NZI & NZI \\
\hline 4 & Cinnamomum verum (Cinnamon) & NZI & NZI & NZI & NZI \\
\hline 5 & Coriandrum sativum (Coriander) & NZI & NZI & NZI & NZI \\
\hline 6 & Curcuma longa (Turmeric) & NZI & NZI & NZI & NZI \\
\hline 7 & Emblica officinalis (Amla) & NZI & NZI & NZI & NZI \\
\hline 8 & Mentha spicata (Mentha) & NZI & NZI & NZI & NZI \\
\hline 9 & Moringa oleifera (Moringa leaves) & NZI & NZI & NZI & NZI \\
\hline 10 & Murraya koenigii (Curry leaves) & NZI & NZI & NZI & NZI \\
\hline 11 & Ocimum sanctum (Tulsi) & NZI & NZI & NZI & NZI \\
\hline 12 & Phyllanthus niruri (Keelanelli) & NZI & NZI & NZI & NZI \\
\hline 13 & Piper nigrum (Black pepper) & NZI & NZI & NZI & NZI \\
\hline 14 & Syzygium aromaticum (Clove) & $10.50^{\mathrm{b}} \pm 0.22$ & NZI & $12.50^{b} \pm 0.34$ & $15.00^{\mathrm{a}} \pm 0.00$ \\
\hline 15 & Trigonella foenum (Fenugreek) & NZI & NZI & NZI & NZI \\
\hline 16 & Zingiber officinale (Dry ginger) & NZI & NZI & NZI & NZI \\
\hline
\end{tabular}

Mean of six observations, values bearing different superscripts within a column differ significantly ( $<<0.05$ ), NZI- No zone of inhibition. 
Table.3 In vitro antimicrobial activity against Staphylococcus aureus, Escherichia coli, Salmonella entitidis and Clostridium perfringens of ethanolic extracts of herbs

\begin{tabular}{|c|c|c|c|c|c|}
\hline \multirow[t]{2}{*}{ S.No } & \multirow[t]{2}{*}{ Name of the herb } & \multicolumn{4}{|c|}{ Antimicrobial activity (Zone of inhibition in $\mathbf{m m}$ ) } \\
\hline & & $\begin{array}{c}\text { Staphyloccous } \\
\text { aureus, }\end{array}$ & $\begin{array}{c}\text { Escherichia } \\
\text { coli }\end{array}$ & $\begin{array}{c}\text { Salmonella } \\
\text { entitidis }\end{array}$ & $\begin{array}{l}\text { Clostridium } \\
\text { perfringens }\end{array}$ \\
\hline 1 & Allium sativum (Garlic) & $14.67^{\mathrm{g}} \pm 0.21$ & NZI & $14.67^{\mathrm{d}} \pm 0.21$ & $\mathrm{NZI}$ \\
\hline 2 & Andrographis paniculata (Nilavembu) & $17.33^{\mathrm{e}} \pm 0.21$ & $17.17^{\mathrm{cd}} \pm 0.31$ & NZI & $16.00^{\mathrm{f}} \pm 0.00$ \\
\hline 3 & Azadirachta indica $(\mathrm{Neem})$ & $14.50^{\mathrm{g}} \pm 0.22$ & $15.83^{\mathrm{fg}} \pm 0.17$ & NZI & NZI \\
\hline 4 & Cinnamomum verum (Cinnamon) & $18.83^{c} \pm 0.16$ & $18.67^{\mathrm{b}} \pm 0.21$ & NZI & NZI \\
\hline 5 & Coriandrum sativum (Coriander) & $14.83^{\mathrm{g}} \pm 0.17$ & $16.83^{\mathrm{de}} \pm 0.17$ & $16.17^{\mathrm{c}} \pm 0.31$ & $18.00^{b} \pm 0.00$ \\
\hline 6 & Curcuma longa (Turmeric) & $17.83^{\mathrm{d}} \pm 0.17$ & $16.33^{\mathrm{ef}} \pm 0.21$ & $17.17^{\mathrm{ab}} \pm 0.17$ & $17.83^{b c} \pm 0.40$ \\
\hline 7 & Emblica officinalis (Amla) & NZI & $17.67^{\mathrm{c}} \pm 0.21$ & NZI & NZI \\
\hline 8 & Mentha spicata (Mentha) & $16.50^{\mathrm{t}} \pm 0.22$ & $15.33^{\mathrm{g}} \pm 0.42$ & $16.00^{c} \pm 0.26$ & $17.00^{\mathrm{d}} \pm 0.00$ \\
\hline 9 & Moringa oleifera (Moringa leaves) & $17.00^{\mathrm{ef}} \pm 0.36$ & $14.67^{\mathrm{h}} \pm 0.21$ & $15.00^{\mathrm{d}} \pm 0.26$ & NZI \\
\hline 10 & Murraya koenigii (Curry leaves) & $16.50^{\mathrm{t}} \pm 0.22$ & $17.50^{\mathrm{c}} \pm 0.22$ & $16.17^{\mathrm{c}} \pm 0.31$ & $19.00^{\mathrm{a}} \pm 0.00$ \\
\hline 11 & Ocimum sanctum (Tulsi) & $17.17^{\mathrm{e}} \pm 0.48$ & $15.67^{\mathrm{g}} \pm 0.76$ & NZI & $17.67^{\mathrm{c}} \pm 0.21$ \\
\hline 12 & Phyllanthus niruri (Keelanelli) & $16.50^{f} \pm 0.22$ & $15.50^{\mathrm{g}} \pm 0.22$ & NZI & NZI \\
\hline 13 & Piper nigrum (Black pepper) & $19.67^{\mathrm{b}} \pm 0.21$ & $17.67^{\mathrm{c}} \pm 0.21$ & NZI & $16.67^{\mathrm{e}} \pm 0.21$ \\
\hline 14 & Syzygium aromaticum (Clove) & $21.00^{\mathrm{a}} \pm 0.00$ & $20.33^{\mathrm{a}} \pm 0.21$ & $17.50^{\mathrm{a}} \pm 0.22$ & $17.00^{d} \pm 0.00$ \\
\hline 15 & Trigonella foenum (Fenugreek) & $18.50^{\mathrm{c}} \pm 0.22$ & $16.67^{\mathrm{de}} \pm 0.21$ & NZI & $15.00^{\mathrm{g}} \pm 0.00$ \\
\hline 16 & Zingiber officinale (Dry ginger) & $16.50^{f} \pm 0.22$ & $16.50^{\mathrm{e}} \pm 0.22$ & $17.00^{b} \pm 0.26$ & NZI \\
\hline
\end{tabular}

Mean of six observations, values bearing different superscripts within a column differ significantly (P<0.05), NZI- No zone of inhibition 
Badei et al., (2002) tested the antimicrobial activities of cardamom, cinnamon and clove essential oils against nine gram-positive bacterial strains, four gram-negative bacterial strains, seven molds, and two yeasts, compared with phenol, using the disc diffusion method. Clove essential oil showed the highest antimicrobial activity, and the antimicrobial spectra (diameter of inhibition zones) of $10 \%$ clove essential oil was 1.48 times as that of $10 \%$ phenol.

Among the ethanol extracts tested Murraya koenigii leaves (Curry leaves) $(19.00 \pm 0.00)$ was found to have highest zone of inhibition against Clostridium Perfringens followed by Coriandrum sativum seeds (Coriander) (18.00 $\pm 0.00)$. The other ethanol extracts had only low zone of inhibition when compared with these two extracts. Ethanol extracts of Allium sativum bulbs (Garlic), Azadirachta indica leaves (Neem), Cinnamomum verum bark (Cinnamon), Emblica officinalis fruit (Amla), Moringa oleifera leaves (Moringa leaves), Phyllanthus niruri stem with leaves (Keelanelli) and Zingiber officinale tuber (Dry ginger) had no activity against Clostridium perfringens. The results are comparable to that of previous studies in which the researchers reported that the various organic extracts of $M$. koenigii exhibited significant antimicrobial activity against both gram positive and gram negative bacteria (Panghal et al., 2011; Baskaran et al., 2011). This property was attributed to several carbazole alkaloids present in the organic extracts of M. Koenigii (Malwal and Sarin, 2011).

In conclusion, aqueous extracts of herbs behaved differently compared to their ethanol extracts in bringing about antibacterial effect. Among the aqueous extracts of herbs, Allium sativum bulbs was the only herb or the herb that had significantly higher antibacterial potency against Staphylococcus aureus,
Escherichia coli, Salmonella entitidis, however, it had no antibacterial activity against Clostridium Perfringens. Ethanol extract of Syzygium aromaticum bud showed the significantly highest antibacterial potency against Staphylococcus aureus, Escherichia coli and Salmonella entitidis and ethanol extracts of Murraya koenigii leaves showed significantly highest antibacterial potency against Clostridium Perfringens.

\section{References}

Aarestrup FM, H.C Wegener, P. Collignon 2008.Resistance in bacteria of the food chain: Epidemiology and control strategies. Expert Review of Anti-Infective Therapy 6:733-750

Badei A.Z.M S.M.M.Faheid, A.T.M.EI - Akel, Barakat Mahmoud (2002) Application of some spices in flavoring and preservation of cookies: 2-antimicrobial and sensory properties of cardamom, cinnamon and clove. vol : 98 Deutsche Lebensmittel Rundschau.

Baskaran Ram. Ramasamy vijayakumar. P.M. Mohan. 2011. Enrichment Method for the Isolation of bioactive Actinomycetes from mangrove sediments of Andaman Islands, India Malaysian journal of microbiology vol: 7: 26-32

Chaieb, K, T. Zmantar, R. Ksouri, H. Hajlaoui, K. Mahdouani, C. Abdelly, A. Bakhrouf. 2007. Antioxidant properties of the essential oil of Eugenia caryophyllata and its antifungal activity against a large number of clinical Candida species. Mycoses.50 (5): 403-6.

Eja ME, BE. Asikong, C. Abriba, G.E. Arikpo, E.E. Anwan, K.H. Enyi-Idoh. 2007. A comparative assessment of the antimicrobial effects of garlic (Allium sativum) and antibiotics on diarrhea genic organisms. Southeast Asian Journal of Tropical Medicine and Public Health. 38(2):343-8.

Fernebro. Jenny. 2011 Fighting bacterial infections - Future treatment options. in Drug resistance updates: reviews and commentaries in antimicrobial and anticancer chemotherapy 14(2):125-39. 
Gadde U, W.H Kim, S.T Oh, H.S Lillehoj (2017) Alternatives to antibiotics for maximizing growth performance and feed efficiency in poultry: a review. Animal Health Research Review 18:26-45

Griffiths, M.D. 2002. The educational benefits of videogames Education and Health, Education and Health. 20 (3):47-51.

Haniyeh Koochak, Seyyed Mansour Seyyednejad, Hussein Motamedi. 2010. Preliminary study on the antibacterial activity of some medicinal plants of Khuzestan (Iran). Asian Pacific Journal of Tropical Medicine 3(3):180-184.

Indu M.N, A. A. M. Hatha, C. Abirosh. U. Harsha G. Vivekanandan 2006. Antimicrobial Activity of some of the south Indian spices against serotypes of Escherichia coli, Salmonella sp, Listeria monocytogenes and Aeromonas hydrophila. Brazilian Journal of Microbiology 37:153-158.

Jombo, G. 2011. Malaria self medications and choices of drugs for its treatment among residents of a malaria endemic community in West Africa. Asian Pacific Journal of Tropical Disease 1(1):10-16.

Malwal, M. and R. Sarin 2011. Antimicrobial efficacy of Murraya koenigii (Linn.) Spreng root extracts. Indian Journal of Natural Products and Resources 2(1)

Panghal, M. V. Kaushal, J.P. Yadav 2011. In vitro antimicrobial activity of ten medicinal plants against clinical isolates of oral cancer cases. Annuals of Clinical Microbiology and Antimicrobials 10(1): 21.

Potdar, R.D, S.A. Sahariah, M. Gandhi, S. HKehoe, N. Brown, N.H. Sane, M. Dayama, S. Jha, A. Lawande, P.J. Coakley,

\section{How to cite this article:}

Kavitha, R., C. Valli, R. Karunakaran, K. Vijayarani and Amutha, R. 2020. Evaluation of Antibacterial Activity of some Indian Herbal Extracts. Int.J.Curr.Microbiol.App.Sci. 9(07): 1724. doi: https://doi.org/10.20546/ijcmas.2020.907.003
E. Marley-Zagar, H. Chopra, D. Shivshankaran P. Chheda-Gala, P MuleyLotankar, G. Subbulakshmi, A.K. Wills, V.A. Cox, V. Taskar, D.J. Barker, A.A. Jackson, B.M. Margetts, C.H. Fall. 2014. Improving women's diet quality pre conceptionally and during gestation: effects on birth weight and prevalence of low birth weight--a randomized controlled efficacy trial in India. American Journal of Clinical Nutrition. 2014 Nov; 100 (5):1257-68

Prabuseenivasan, S, M. Jayakumar Savarimuthu, Ignachimuthu. 2006. In vitro antibacterial activity of some plant essential oils. BMC Complement Alternate Medicine 6:39-46

Saeed S, Tariq P. 2007. Antibacterial activities of Emblica officinalis and Coriandrum sativum against Gram negative urinary pathogens. Pakistan Journal of Pharmacological Science. 20(1): 32-5.

Srivastava, M., A. Ahuja, S. Kachhwaha, Naveen Kumar Singh. 2013. Management of Idiopthic urticaria in horses Short Communication article history abstract.

Tiwari, B. Anil Chaudhary, Ashutosh Mishrac, D. Ganesh Bhatt. 2010 Anti-Inflammatory effects of the saponins obtained from the leaves of Acorus Calamus. Pharmacology online 2: 395-400

Vijayalakshmi, K. Preethi and J. M. Sasikumar 2010. In vitro cytotoxic effects of Evoluvlu salsinoides linn leaves against human cancer cell lines Pharmacology online 3: 409-414.

Walsh. 2003. Antibiotics: Actions, origins, resistance, Washington, DC: ASM Press. Reviewed by Hans Von Döhren 